\title{
Effect of Coenzyme Q10 on Plasma Parameters in Hypothyroid Rats
}

\author{
Ali Osman iNAN ${ }^{1, a,{ }^{*}}$, Zafer DURGUN ${ }^{2, b}$, Oğuzcan KOCA ${ }^{3, c}$, Durmuş HATiPOĞLU ${ }^{2, d}$ \\ ${ }^{1}$ Republic Of Turkey, Ministry Of National Education, Akşehir, Konya, Turkey \\ ${ }^{2}$ Selcuk University, Faculty of Veterinary Medicine, Department of Physiology, Konya, Turkey \\ ${ }^{3}$ Republic Of Turkey, Ministry Of Agriculture And Forestry, Artvin, Turkey \\ aORCID: 0000-0001-7464-4405, ' ORCID: 0000-0002-9385-638X , 'ORCID: 0000-0001-5311-3111, \\ dORCID: 0000-0003-3790-7821
}

Geliş Tarihi: 22.02.2021

Kabul Tarihi: 31.05.2021

\begin{abstract}
This research was conducted to determine the effect of Coenzyme Q10 (CoQ10) on blood glucose, total protein, triglyceride, and total cholesterol levels in rats for that experimental hypothyroidism was induced. A total of 32 healthy adult male Wistar Albino rats were used as a material in the research. After the adaptation period of animals for ten days, the main research period was conducted for a total of three weeks. The rats housed as four rats in each cage during the research were divided into four experimental groups as control (K), CoQ10 (C), Hypothyroid $(\mathrm{H})$, and CoQ10+Hypothyroid (CH). CoQ10 was administered intraperitoneally every day to the group $\mathrm{C}$ animals. In addition, propylthiouracil (PTU) was added daily to the water of rats in group $\mathrm{H}$ to induce experimental hypothyroidism. Both CoQ10 and PTU administration was performed on the animals in the group HC. At the end of the trial period, blood was drawn from the hearts of rats in all groups. Glucose, total protein, triglyceride, and total cholesterol levels were determined in plasma samples obtained from blood samples. It was observed in the research that hypothyroidism administration (group $\mathrm{H}$ ) decreased plasma glucose and triglyceride values $(p<0.05)$ and increased total protein and total cholesterol levels $(p<0.05)$ compared to group $\mathrm{K}$. In the study, it was observed that while CoQ10 administration (group HC) did not have a statistically significant effect on plasma glucose, total protein and triglyceride values in hypothyroidism-induced rats (group $\mathrm{H}$ ), it increased the total cholesterol level $(p<0,05)$. In the research, it was observed that the CoQ10 administration (group $\mathrm{C}$ ) decreased plasma triglyceride values compared to that of group $\mathrm{K}(\mathrm{p}<0.05)$. As a result, since CoQ10 administration increases total cholesterol level in hypothyroidism, the effect of CoQ10 supplementation on blood lipid profile in metabolic diseases should be considered.
\end{abstract}

Keywords: CoQ10, hypothyroidism, plasma parameters, rat, thyroid hormones.

\section{Hipotiroidili Ratlarda Koenzim Q10'un Plazma Parametreleri Üzerine Etkisi}

Özet: Deneysel olarak hipotiroidizm oluşturulmuş ratlarda Koenzim Q10 (KoQ10)'un kan glikoz, total protein, trigliserit ve total kolesterol düzeyleri üzerindeki etkisinin belirlenmesi amaçlandı. Araştırmada materyal olarak sağlıkı toplam 32 adet yetişkin erkek Wistar Albino ırkı rattan yararlanıldı. Hayvanların10 günlük adaptasyon süresini takiben esas araştırma dönemi toplam 3 hafta sürdürüldü. Çalışma süresince her kafeste 4 rat olacak şekilde barındırılan ratlar kontrol (K), KoQ10 (C), Hipotiroid $(\mathrm{H})$ ve KoQ10+ Hipotiroid $(\mathrm{CH})$ olmak üzere 4 deneme grubuna ayrıldı. C grubu hayvanlara her gün intraperitoneal olarak KoQ10 uygulandı. Deneysel hipotiroidizm oluşturmak amacıyla, $\mathrm{H}$ grubundaki ratların sularına günlük propiltiyourasil (PTU) ilave edildi. HC grubundaki hayvanlara ise hem KoQ10, hem de PTU uygulaması yapıldı. Deneme sonunda gruplardaki deneklerden genel anestezi altında kardiak punksiyon ile yeterli oranda kan alındı ve plazmaları elde edildi. Elde edilen plazma örneklerinden glikoz, total protein, trigliserit ve total kolesterol düzeyleri belirlendi. Araştırmada, hipotiroidizm oluşturulmasının, kontrol grubu ile kıyaslandığında plazma glikoz ve trigliserit değerlerini düşürdüğü $(p<0,05)$, total protein ve total kolesterol düzeylerini arttırdığı $(p<0,05)$ gözlendi. Çalışmada, KoQ10 tedavisinin (HC grubu), hipotiroidizm oluşturulan ratlar ile kıyaslandığında ( $\mathrm{H}$ grubu) plazma glikoz, total protein ve trigliserit değerleri üzerinde istatistiksel öneme sahip bir etkisi belirlenemezken, total kolesterol düzeyini artırdığı görüldü( $p<0,05)$. Araştırmada KoQ10 (C grubu) uygulamasının, K grubuna göre plazma trigliserit değerlerini azalttığı $(p<0,05)$ görüldü. Sonuç olarak hipotiroidide, CoQ10 uygulaması toplam kolesterol düzeyini arttırdığından, metabolik hastalıklarda CoQ10 takviyesinin kan lipit profili üzerindeki etkisi göz önünde bulundurulmalıdır.

Anahtar Kelimeler: CoQ10, hipotiroidizm, plazma parametreleri, rat, tiroid hormonları.

\section{Introduction}

The thyroid gland begins as a rapidly changing process of concentrating iodide in the $11^{\text {th }}$ week of pregnancy and matures rapidly, becoming one of the most important endocrine systems in the human body (Wolmarans, 2017). The thyroid hormones play a critical role in facilitating normal growth and development while also directing and regulating numerous physiological processes throughout adulthood (Melmed et al., 2015). These include central nervous system (CNS) development, 
central and peripheral nervous system signaling, heart function, nutrient metabolism, hepatic metabolism, energy consumption and regulation of body temperature, water and electrolyte balance, and skeletal cycle (Melmed et al., 2015).

Thyroid hormones have a dose-dependent adverse effect on carbohydrate metabolism. As the thyroid hormone level increases in the blood, the absorption of glucose from the intestines and the use of glucose by the tissues increase; glycogenolysis and gluconeogenesis in the liver, skeletal muscle, and cardiac muscle cells are stimulated, and blood glucose level increases (Noyan, 2011). Triiodothyronine $\left(T_{3}\right)$ can cause changes in the energy metabolism of the whole body (Vinales et al., 2019). T3, which increases the sensitivity of hepatocytes to the glycogenolytic and gluconeogenic effects of epinephrine, indirectly affects hepatic glucose production and increases the use of glucose by muscle cells (Salvatore et al., 2014). Thus, hypothyroidism has a significant effect on an individuals glucose tolerance, post-meal thermogenesis, and sympatho-adrenergic reactions to glucose uptake (Kozacz et al., 2014; Mullur et al., 2014). Thyroid dysfunction may be a risk factor for glucose intolerance (Nishi, 2018), and glucose absorption is impaired in hypothyroidism, peripheral glucose assimilation is delayed, and gluconeogenesis is slower (Duntas et al., 2011).

Thyroid hormone regulation of lipid metabolism, mainly depends on the liver-specific effects of the interactions of $T_{3}$, thyroid hormone receptors, and nuclear hormone receptors. Thyroid hormones regulate cholesterol synthesis through many mechanisms (Mullur et al. 2014). The main pathway is the stimulation of transcription of the LDL-R gene by thyroid hormones, resulting in increased cholesterol uptake and cholesterol synthesis (Lopez et al., 2007). Fatty acids induce hepatic thyroid hormone receptor expression and decrease both serum cholesterol and serum triglycerides; however, in the case of hypothyroid, polyunsaturated fatty acid does not induce thyroid hormone receptors, but it causes a decrease in serum cholesterol, resulting in persistent hypertriglyceridemia by stimulating PPAR expression (Souza et al., 2011). In the case of hypothyroidism, it is stated that serum low-density lipoprotein (LDL) and cholesterol levels increase due to the decrease of LDL receptors in the liver (Diekman et al. 1998; Shin and Osborne, 2003). Thyroid hormones stimulate protein conversion (Marcin et al., 2016). The effect of thyroid hormones on protein metabolism differs from the organism's metabolic state and hormone level. Physiological doses of the hormone increase the synthesis rate of the necessary enzymes in oxidative reactions required for protein synthesis and ultimately create a positive nitrogen balance (Noyan, 2011). Hypothyroidism causes a decrease in protein synthesis and the release of amino acids such as alanine, tyrosine, glycine, and glutamine from skeletal muscles (Marcin et al., 2016).

CoQ10 is an important coenzyme found in the hydrophobic part of all membranes and the mitochondrial inner membrane and is necessary for the activities of enzyme systems involved in oxidation-reduction reactions in the electron transfer chain (Acosta et al., 2016; Alcázar-Fabra et al.; 2016). Under normal conditions, the amount synthesized in the body is sufficient for the body. However, various diseases, aging, and degenerative processes cause this amount to be insufficient for the body (Bhagavan and Chopra, 2006).

In this context, against the negative metabolic effects of hypothyroidism, which has negative effects on many systems in humans and animals and which is endemic both in Turkey and in the world; although it is produced endogenously in the body, it is aimed to determine the effect of CoQ10, for which insufficiency can be observed and has become widely used as a food supplement in recent years, on plasma glucose, total protein, triglyceride and total cholesterol levels in experimental hypothyroidism-induced rats.

\section{Material and Methods}

A total of 32 healthy adult male Wistar Albino rats were used as the material in the research. Animals were taken from Selcuk University, Experimental Medicine Research and Application Center. During the research period, the predicted living conditions for the rats were provided as $22 \pm 2$ oc room temperature, $50 \pm 10 \%$ relative humidity, and $12 / 12$ night and daylight periods. The animals were fed ad libitum with standard rat feed, and the average amount of water in the rats' daily drink Table was determined $(50 \mathrm{ml} / \mathrm{day} / \mathrm{rat})$, and their water was refreshed daily during the 10-day adaptation period. The main research period in the study was conducted for a total of 3 weeks.

The rats housed in 8 separate cages (each group divided into two separate cages) as four rats in each cage during the research were divided into four experimental groups as control $(K, n=8)$, CoQ10 $(\mathrm{C}, \mathrm{n}=8), \quad$ Hypothyroid $(\mathrm{H}, \mathrm{n}=8), \quad$ and CoQ10+Hypothyroid $(\mathrm{CH}, \mathrm{n}=8)$.

Control Group (K): No administration was made to the animals in this group, and their feed was given ad libitum during the study, while their daily drinking water was given in the specified amount. 
Coenzyme Q10 Group (C): During the trial, approximately $3 \mathrm{mg}$ CoQ10 (10mg/kg/day) per animal was administered intraperitoneally by dissolving in $0.3 \mathrm{ml}$ corn oil for this group of rats (Keskin and Uluışık, 2017).

Hypothyroidism Group (H): To induce hypothyroidism in rats, 6-n-propyl-2-thiouracil (PTU) was added to drinking water at the rate of $10.05 \%$ weight/volume $(\mathrm{w} / \mathrm{v})$ daily throughout the trial (Messarah et al., 2010; Tousson et al., 2012).

Hypothyroidism + Coenzyme Q10 Group (HC): Coenzyme Q10 dissolved in corn oil at an amount of $10 \mathrm{mg} / \mathrm{kg} /$ day was administered intraperitoneally to the animals in this group throughout the trial. $0.05 \%$ of PTU was added to drinking water.

At the end of the research, a sufficient amount of blood was drawn from the subjects in the groups under general anesthesia $(70 \mathrm{mg} / \mathrm{kg}$ ketamine +5 $\mathrm{mg} / \mathrm{kg}$ Rompun) and cardiac punching into EDTA tubes. Plasma was obtained by centrifuging the blood at +4 o $C$ at $3500 \mathrm{rpm}$ (Hettich Rotina $35 \mathrm{R}$ ). Total protein, glucose, triglyceride, and total cholesterol levels were determined in the obtained plasma samples. Animals whose blood was drawn were sacrificed by the appropriate euthanasia technique (cervical dislocation). Plasma samples obtained from blood drawn from animals were stored at $-20^{\circ} \mathrm{C}$ until the analysis is performed. The study was approved by the Selcuk University Experimental Medicine Research and Application Center Ethics Committee (Report no.2018-49).

Total protein (Siemens, Df73), glucose (Siemens, Df39a), triglyceride (Siemens, Df69a), and total cholesterol (Siemens, Df27) levels were determined spectrophotometrically with the Siemens Centaur CP device as per the kit IFUs (Castelo-Branco et al. 2010).

Statistical analysis of the data obtained at the end of the study was carried out using the SPSS 18.0 (SPSS, Inc., Chicago, IL, USA) package program. Variance analysis was conducted to determine the importance of intergroup differences in the research. Duncan multiple comparison tests were performed for post hoc analysis (Tekin, 2003).

\section{Results}

While the mean plasma GLU value determined in the study was not significant between Group $\mathrm{K}$ and $\mathrm{C}$ and between Group $\mathrm{H}$ and $\mathrm{HC}$, it showed a significant decrease $(p<0.05)$ in both Group $\mathrm{H}$ and $\mathrm{C}$ compared to Group $\mathrm{K}$ and $\mathrm{C}$. In addition, it was observed that the application of inducing experimental hypothyroidism was influential on the average glucose value, while the application of CoQ10 did not cause any change (Table 1 and Figure 1).

Table 1. Plasma average glucose $(m g / d l)$, total protein $(g / d l)$, triglyceride $(m g / d l)$ and cholesterol $(m g / d l)$ values of all groups. $(x x \pm S E M, n=8)$.

\begin{tabular}{ccccc}
\hline Parameters & K & C & H & HC \\
\hline GLU & $233 \pm 16,38^{\mathrm{a}}$ & $231,25 \pm 10,38^{\mathrm{a}}$ & $185,5 \pm 12,15^{\mathrm{b}}$ & $187,12 \pm 11,03^{\mathrm{b}}$ \\
TP & $5,48 \pm 0,05^{\mathrm{b}}$ & $5,67 \pm 0,1^{\mathrm{b}}$ & $6,46 \pm 0,17^{\mathrm{a}}$ & $6,76 \pm 0,08^{\mathrm{a}}$ \\
TG & $65,85 \pm 3,68^{\mathrm{a}}$ & $51,62 \pm 6,32^{\mathrm{b}}$ & $30,87 \pm 1,39^{\mathrm{c}}$ & $25,25 \pm 2,30^{\mathrm{c}}$ \\
TC & $68,0 \pm 1,52^{\mathrm{c}}$ & $67,75 \pm 1,89^{\mathrm{c}}$ & $83,37 \pm 4,5^{\mathrm{b}}$ & $97,12 \pm 4,79^{\mathrm{a}}$ \\
\hline
\end{tabular}

$\mathbf{a}, \mathbf{b}, \mathbf{c} ;$ The difference between the mean values of the same parameter with different letters on the same row is important. $(p<0,05)$.
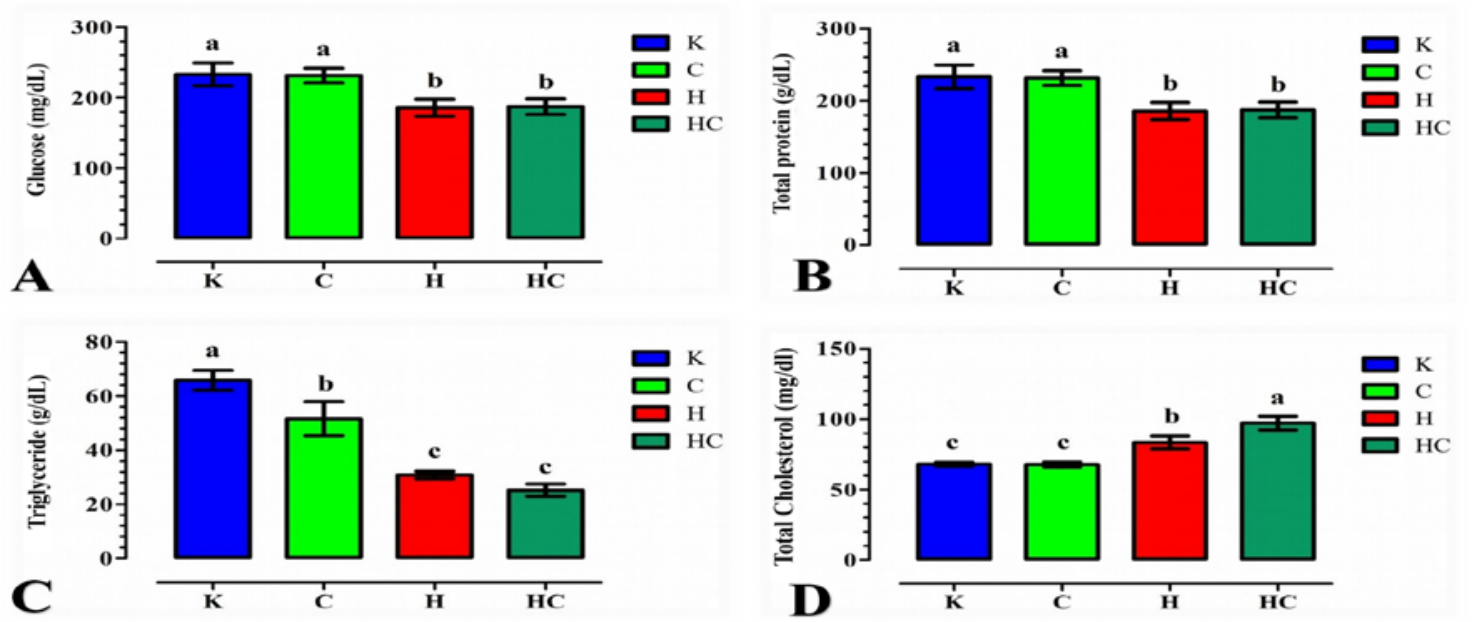

Figure 1. A. Plasma average glucose values B. Plasma average total protein values C. Plasma average triglyceride values, D. Plasma mean total cholesterol values 
While the plasma means total protein value determined in the study was not significant between Group $\mathrm{K}$ and $\mathrm{C}$ and between Group $\mathrm{H}$ and $H C$, it showed a significant increase $(p<0.05)$ separately in both Group $\mathrm{H}$ and $\mathrm{C}$ compared to Group K and C. It was observed that the application of inducing experimental hypothyroidism was effective on the average total protein value, while the application of CoQ10 did not cause any change (Table 1 and Figure 1).

The mean plasma triglyceride value determined in the research showed a decrease $(p<0.05)$ in Group $\mathrm{C}, \mathrm{H}$, and $\mathrm{HC}$ compared to that of Group K. The inter-value difference between the Group $\mathrm{H}$ and $\mathrm{HC}$ was insignificant. The application of inducing experimental hypothyroidism was found to be significantly $(p<0.05)$ effective on the decrease in plasma mean triglyceride value; while the CoQ10 application was found to be significant in Group C compared to Group K $(p<0.05)$, and insignificant in the Group $\mathrm{HC}$ compared to Group $\mathrm{H}$ (Table 1 and Figure 1)

In this study, while the plasma average total cholesterol value determined was not statistically significant between Group K and Group C; it increased significantly $(p<0.05)$ in both Group $\mathrm{H}$ and Group HC compared to the groups in subject ( $\mathrm{K}$ and $\mathrm{C}$ ). The increase in Group $\mathrm{HC}$ was significant compared to Group H $(p<0.05)$. It was observed that the experimental hypothyroidism application had a significant $(p<0.05)$ effect on the increase of the mean plasma total cholesterol value. Also, application of CoQ10 further increased the increased total cholesterol value in hypothyroidism $(p<0.05)$ (Table 1 and Figure 1$).$

\section{Discussion and Conclusion}

Numerous health benefits of CoQ10 supplementation are reported in the literature. A significant part of the studies on this subject is related to cardiovascular diseases in which the effect of CoQ10 is investigated as a part of medical treatment (Belardinelli et al., 2006; Dludla et al., 2020; Hernández-Camacho et al., 2018, Mantle and Hargreaves, 2019). Also, CoQ10 is recommended to be used as an auxiliary or protective support agent in the treatment of neurodegenerative diseases and mitochondrial diseases (Yang et al., 2016), neurological diseases such as Parkinson and Huntington (McGarry et al., 2017; Zhu et al., 2017), and diabetes (Samimi et al., 2019) and cancer cases (Abdi et al., 2020; Tafazoli, 2017). Also, in the studies conducted, it was shown that CoQ10 plays a role in stabilizing free radicals due to its powerful antioxidant function, and by this characteristic, it prevents the damage of biomolecules by inhibiting lipid and protein peroxidation, and it is noted that it is useful as a protective agent in some diseases and as an auxiliary in treatment (Alahmar and Sengupta, 2020; Mousavinejad et al., 2018; Samimi et al., 2019). Even then, the number of researches on the effect of CoQ10 on impaired metabolism and related parameters in hypothyroidism is quite insufficient.

It is emphasized that there is a tendency to increase in serum CoQ10 level in case of hypothyroidism, and there is an inverse correlation between serum CoQ10 level and serum thyroid hormones ( $\mathrm{fT}_{3}, \mathrm{fT}_{4}, \mathrm{rT3}$, and $\mathrm{rT}_{4}$ ) levels (Ogura et al. 1980). The reasons for the decrease in CoQ10 levels have been reported as thyroid hormone levels rise, CoQ10 works against tyrosine, the substrate for thyroxine synthesis, and increased use of CoQ10 and increased degradation due to increased metabolic (Polat et al., 2017). Similarly, Pandolfi et al. (1994) reported that the blood CoQ10 levels of patients with hypothyroidism increased, and they emphasized that CoQ10 was inversely related to $T_{3}$ but had no relation to $T_{4}$. It is thought that the decrease in $T_{3}$ level due to CoQ10 administration may be due to the increased intracellular use of this hormone as a result of accelerated mitochondrial activity (Pandolfi et al., 1994).

In this study, the fact that the plasma glucose, total protein, triglyceride, and total cholesterol levels of the group C given CoQ10 did not differ significantly $(p>0.05)$, and the plasma glucose and triglyceride levels in the group HC given CoQ10 with PTU were statistically lower than in the group $\mathrm{K}$ $(p<0.05)$ and total protein level was statistically high $(p<0.05)$ showed that CoQ10 was not effective in correcting the plasma glucose, total protein and triglyceride levels due to hypothyroidism. In the study, the total cholesterol level was found to be statistically higher in the group PTU than in group $\mathrm{K}$ and Group $C(p<0.05)$. In the group HC given CoQ10 with PTU, total cholesterol level was found to be statistically higher than all other groups $(K, C$, and H) $(p<0.05)$ (Table 1).

It is reported that thyroid hormones increase glycogen synthesis in small doses within the context of dose-dependent adverse effects (Cooper et al., 2007; Noyan, 2011). It is also reported that basal metabolism slows down, and gluconeogenesis decreases in hypothyroidism (Comte et al., 1990; Marchesini et al., 1993). These reports support the decrease in mean plasma glucose level achieved in the hypothyroidism group in the study. The decrease determined in plasma glucose level in group $\mathrm{H}$ may be due to the decrease in phosphorylase kinase and lysosomal $\alpha$-oxidase activity in the liver, and thus glycogenolysis due to the decrease in $\mathrm{T}_{3}$ level, and may also be due to a 
decrease in gluconeogenic enzyme activities such as phosphoenolpyruvate, carboxykinase, and pyruvate carboxylase, and decreased susceptibility to glycogenolysis and gluconeogenesis in hepatocytes. The reports that CoQ10 administration does not affect plasma glucose and the result obtained in the study are similar (Kismali, 2009). (Table 1 and Figure 1).

Thyroid hormones are necessary for cells to synthesize structural proteins and specific enzymes, therefore for growth. It was reported that the role of thyroid hormones on protein metabolism is biphasic, catabolic in high concentrations, and anabolic in low concentrations (Trajkovic-Arsic et al., 2010). It was reported that hyperthyroidism prevents protein synthesis, accelerates protein catabolism, and increases nitrogen excretion, and the hormone administered in physiological doses increases protein synthesis (Noyan, 2011) also. In hypothyroidism, it was reported that in patients whose basal metabolic rate and protein synthesis and degradation decrease, a positive nitrogen balance occurs, protein permeability of capillaries increases, and protein level increases in effusions (Hayase et al., 1991). In the study, the increase in total protein level in group $\mathrm{H}$ compared to the group $\mathrm{K}$ group was attributed to the increase in the synthesis rate due to protein degradation. The increase in the total protein level determined in group $\mathrm{H}$ compared to group $\mathrm{K}$ in the study does not match with the reports that there is no change in the parameter in question (Kandir and Keskin, 2016; Kismali, 2009) (Table 1 and Figure 1).

The general conclusion in the literature is that plasma total cholesterol and triglyceride levels increase in hypothyroidism. Lipoprotein lipase (LPL) plays a central role in plasma lipid metabolism, hydrolyzing triglycerides in lipoproteins and releasing fatty acids for tissues (Beigneux et al., 2019). Lipoprotein lipase activity is increased by thyroid hormone, so the triglyceride level may increase in hypothyroidism (Lam et al., 1986). However, Ness et al. (1998) reported that plasma triglycerides decreased by $60 \%$ as a result of thyroidectomy in rats. The results we obtained in our study showed that the decrease in triglyceride level in the hypothyroidism-induced group compared to the control group showed that more detailed studies are needed on this subject. Also, it was observed in our research that PTU administration caused an increase in total cholesterol levels in group $\mathrm{H}$ compared to group $\mathrm{K}$, which was similar to the reports of many researchers (Cooper et al., 2007; Meisinger et al., 2014; Ness et al., 1998).
Although the main reason for CoQ10's effect on lipid profile is unknown, several mechanisms by which CoQ10 supplements can improve lipid profiles are reported. As an intracellular antioxidant, CoQ10 protects cell membrane phospholipids and mitochondrial membrane protein against damage caused by free radicals (Singh et al. 2007). Aldehyde derivatives from lipid peroxidation such as malondialdehyde inhibit free cholesterol esterifying, lecithin-cholesterol acyltransferase (LCAT) on HDL-cholesterol. Hence, CoQ10 can support the production of HDLcholesterol, suppress oxidative stress, and reduce malondialdehyde levels (McCall et al. 1995). Besides, CoQ10 supplementation activates the calcium-mediated AMP-activated protein kinase pathway (AMPK, the molecule that stimulates mitochondrial biogenesis, glucose transport, and free fatty acid oxidation) and provides inhibition of differentiation-induced adipogenesis (Lee et al., 2012). According to the findings we obtained in our study, although plasma triglyceride level in group C treated with CoQ10 tended to decrease compared to group $K$, this difference was not significant $(p>0.05)$. Although the plasma triglyceride level of Group HC is statistically the lowest $(p<0.05)$ and the total cholesterol level is statistically the highest $(p<0.05)$ differs from other literature reports (Table 1 and Figure.1), this may be since the duration of experimental hypothyroidism is only three weeks. Hypothyroidism patients who require urgent intervention are patients with thyroid hormone insufficiency for a long time.

In this study, it was determined that CoQ10 administration decreased the mean plasma triglyceride level in group $\mathrm{C}$ compared to group $\mathrm{K}$ and increased the mean plasma cholesterol level in group $\mathrm{HC}$ compared to group $\mathrm{H}$. Also, literature data on the effect of CoQ10 on lipid profile differ. It was concluded that the difference in the data obtained in the study and from the current literature might be due to the differences in the use, dosage, and duration of use of CoQ10 and the species used as material. Conducting a detailed and sufficient number of researches on the subject will ensure that the subject can be discussed more scientifically.

\section{Acknowledgments}

This manuscript was compiled from the project supported by Selcuk University Scientific Research Projects Coordinator. 


\section{References}

Abdi S, Montazeri V, Garjani A, Shayanfar A, Pirouzpanah $S$, 2020: Coenzyme Q10 in association with metabolism-related AMPK/PFKFB3 and angiogenic VEGF/VEGFR2 genes in breast cancer patients. $\mathrm{Mol}$ Biol Rep, 47 (4), 2459-2473.

Acosta MJ, Fonseca LV, Desbats MA, Cerqua C, Zordan R, Trevisson E, Salviati L, 2016: Coenzyme Q biosynthesis in health and disease. BBABioenergetics, 1857(8), 1079-1085.

Alahmar AT, Sengupta P, 2020: Impact of Coenzyme Q10 and Selenium on Seminal Fluid Parameters and Antioxidant Status in Men with Idiopathic Infertility. Biol Trace Elem Res, 1-7.

Alcázar-Fabra M, Navas P, Brea-Calvo G, 2016: Coenzyme $Q$ biosynthesis and its role in the respiratory chain structure. BBA-Bioenergetics, 1857(8), 1073-1078.

Beigneux AP, Allan CM, Sandoval NP, Cho GW, Heizer PJ, Jung RS, Stanhope KL, Havel PJ, Birrane G, Meiyappan M, 2019: Lipoprotein lipase is active as a monomer. PNAS-USA, 116(13), 6319-6328.

Belardinelli R, Muçaj A, Lacalaprice F, Solenghi M, Seddaiu G, Principi F, Tiano L, Littarru GP, 2006: Coenzyme Q10 and exercise training in chronic heart failure. Eur Heart J, 27 (22), 2675-2681.

Bhagavan HN, Chopra RK, 2006: Coenzyme Q10 absorption, tissue uptake, metabolism and pharmacokinetics. Free Radic. Res, 40 (5), 445-453.

Castelo-Branco C, Steinvarcel F, Osorio A, Ros C, Balasch J, 2010: Atherogenic metabolic profile in PCOS patients: role of obesity and hyperandrogenism. Gynecol Endocrinol, 26 (10), 736-742.

Comte B, Vidal H, Laville M, Riou J-P, 1990: Influence of thyroid hormones on gluconeogenesis from glycerol in rat hepatocytes: a dose-response study. Metab Clin Exp, 39 (3), 259-263.

Cooper D, Greenspan F, Ladenson P, 2007 Hyperthyroidism and Thyrotoxicosis. Greenspan's basic and clinical endocrinology, 8th edition : 248252.

Diekman T, Demacker PN, Kastelein JJ, Stalenhoef AF, Wiersinga WM, 1998: Increased oxidizability of lowdensity lipoproteins in hypothyroidism. J Clin Endocrinol Metab, 83(5): 1752-1755.

Dludla PV, Nyambuya TM, Orlando P, Silvestri S, Mxinwa $\mathrm{V}$, Mokgalaboni K, Nkambule BB, Louw J, Muller CJ, Tiano L, 2020: The impact of coenzyme Q10 on metabolic and cardiovascular disease profiles in diabetic patients: A systematic review and meta-analysis of randomized controlled trials. Endocrinol Diabetes Metab, 3 (2), e00118.

Duntas LH, Orgiazzi J, Brabant G, 2011: The interface between thyroid and diabetes mellitus. Clinical Endocrinology, 75 (1), 1-9.

Hayase K, Yonekawa G, Yokogoshi H, Yoshida A, 1991: Triiodothyronine administration affects urea synthesis in rats. J Nutr, 121 (7), 970-978.

Hernández-Camacho JD, Bernier M, López-Lluch G, Navas $P$, 2018: Coenzyme Q10 supplementation in aging and disease. Front Physiol, 9, 44.
Kandir S, Keskin E, 2016: Effects of hypothyroidism and hyperthyroidism on hematological parameters in rats. Ankara Univ Vet Fak Derg, 63 (4), 371-376.

Keskin E, Uluisik D, 2017: Hematological effects of Coenzyme Q10 in streptozotocin-induced diabetic rats. Eurasian J Vet Sci, 33 (3), 167-71.

Kismali G, 2009: Effects of Coenzyme Q10 on blood biochemistry in rats. Kafkas Univ Vet Fak Derg, 15 (2), 191-194.

Kozacz A, Grunt P, Steczkowska M, Mikulski T, Dąbrowski J, Górecka M, Sanocka U, Ziemba AW, 2014: Thermogenic effect of glucose in hypothyroid subjects. Int J Endocrinol, 308017-308017.

Lam KS, Chan MK, Yeung RT, 1986: High-density lipoprotein cholesterol, hepatic lipase and lipoprotein lipase activities in thyroid dysfunction effects of treatment. QJM-INT J MED, 59 (2), 513521.

Lee SK, Lee JO, Kim JH, Kim N, You GY, Moon JW, Sha J, Kim SJ, Lee YW, Kang HJ, 2012: Coenzyme Q10 increases the fatty acid oxidation through AMPKmediated PPAR $\alpha$ induction in 3T3-L1 preadipocytes. Cell Signal, 24 (12), 2329-2336.

Lopez D, Abisambra Socarrás JF, Bedi M, Ness GC, 2007: Activation of the hepatic LDL receptor promoter by thyroid hormone. BBA; 1771(9): 1216-1225.

Mantle D, Hargreaves I, 2019: Coenzyme Q10 and degenerative disorders affecting longevity: an overview. Antioxidants, 8 (2), 44.

Marchesini G, Fabbri A, Bianchi G, Motta E, Bugianesi E, Urbini D, Pascoli A, Lodi A, 1993: Hepatic conversion of amino nitrogen to urea nitrogen in hypothyroid patients and upon L-thyroxine therapy. Metab Clin Exp, 42 (10), 1263-1269.

Marcin G, Maria S, Marcin RT, Krzysztof L, Magdalena G, Łukasz K, Marcin S, Piotr W, 2016: Content of selected amino acids in the gastrocnemius muscle during experimental hypothyroidism in rats. $J$ Vet Res, 60 (4), 489-493.

McCall MR, Tang JY, Bielicki JK, Forte TM, 1995: Inhibition of lecithin-cholesterol acyltransferase and modification of HDL apolipoproteins by aldehydes. Arterioscler Thromb Vasc Biol, 15 (10), 1599-1606.

McGarry A, McDermott M, Kieburtz K, de Blieck EA, Beal F, Marder K, Ross C, Shoulson I, Gilbert P, Mallonee WM, 2017: A randomized, double-blind, placebocontrolled trial of coenzyme Q10 in Huntington disease. $A A N, 88$ (2), 152-159.

Meisinger $C$, Ittermann $T$, Tiller $D$, Agger $C$, Nauck $M$, Schipf S, Wallaschofski H, Jørgensen T, Linneberg A, Thiery J, 2014: Sex-specific associations between thyrotropin and serum lipid profiles. Thyroid, 24 (3), 424-432.

Melmed S, Polonsky KS, Larsen PR, Kronenberg HM, 2015: Williams Textbook of Endocrinology E-Book. Elsevier Health Sciences.

Messarah M, Boumendjel A, Chouabia A, Klibet F, Abdennour C, Boulakoud MS, Feki, AE, 2010: Influence of thyroid dysfunction on liver lipid peroxidation and antioxidant status in experimental rats. Exp Toxicol Pathol, 62, 301-310.

Mousavinejad E, Ghaffari MA, Riahi F, Hajmohammadi M, Tiznobeyk Z, Mousavinejad M, 2018: Coenzyme Q10 
supplementation reduces oxidative stress and decreases antioxidant enzyme activity in children with autism spectrum disorders. Psychiatry Res, 265, 62-69.

Mullur R, Liu Y-Y, Brent GA, 2014: Thyroid hormone regulation of metabolism. Physiological reviews, 94 (2), 355-382.

Ness GC, Lopez D, Chambers CM, Newsome WP, Cornelius P, Long CA, Harwood Jr HJ, 1998: Effects of L-triiodothyronine and the thyromimetic L-94901 on serum lipoprotein levels and hepatic low-density lipoprotein receptor, 3-hydroxy-3-methylglutaryl coenzyme A reductase, and apo Al gene expression. Biochem Pharmacol, 56 (1), 121-129.

Nishi M, 2018: Diabetes mellitus and thyroid diseases. Diabetology International, 9 (2), 108-112.

Noyan A, 2011: Yaşamda ve Hekimlikte Fizyoloji.(1. Baskı). İstanbul: Palme Yayıncılık : 483-488.

Ogura F, Morii H, Ohno M, Ueno T, Kitabatake S, Hamada $\mathrm{N}$, Ito K, 1980: Serum coenzyme Q10 levels in thyroid disorders. Horm Metab Res, 12 (10), 537540.

Pandolfi C, Ferrari D, Stanic I, Pellegrini L, 1994: Circulating levels of CoQ10 in hypo-and hyperthyroidism. Minerva Endocrinol, 19 (3), 139142.

Polat M, Polat Y, Akbulut T, Cinar V, Marangoz I, 2017: The effects of trainings applied with CoQ10 and zinc supplementation on the thyroid hormone metabolism in Soccer players. Biomed.Res., 28 (16),7070-7075.

Salvatore D, Simonides WS, Dentice M, Zavacki AM, Larsen PR, 2014: Thyroid hormones and skeletal muscle-new insights and potential implications. Nature Reviews Endocrinology, 10 (4), 206-214.

Samimi F, Baazm M, Eftekhar E, Rajabi S, Goodarzi MT, Mashayekhi FJ, 2019: Possible antioxidant mechanism of coenzyme Q10 in diabetes: impact on Sirt1/Nrf2 signaling pathways. Res Pharm Sci, 14 (6), 524.

Shin D-J, Osborne TF, 2003: Thyroid hormone regulation and cholesterol metabolism are connected through sterol regulatory element-binding protein-2 (SREBP2). J Biol Chem, 278 (36), 34114-34118.
Singh U, Devaraj S, Jialal I, 2007: Coenzyme Q10 supplementation and heart failure. Nutr Rev, 65 (6), 286-293.

Souza LL, Cordeiro A, Oliveira LS, de Paula GS, Faustino LC, Ortiga-Carvalho TM, Oliveira KJ, Pazos-Moura CC, 2011: Thyroid hormone contributes to the hypolipidemic effect of polyunsaturated fatty acids from fish oil: in vivo evidence for cross talking mechanisms. J Endocrinol, 211 (1), 65-72.

Tafazoli A, 2017: Coenzyme Q10 in breast cancer care. Future Oncology, 13 (11), 1035-1041.

Tekin M, 2003: Örneklerle bilgisayarda istatistik. SÜ Veteriner Fakültesi Yayın Ünitesi, Konya

Tousson E, Ali EM, Ibrahim W, Mansour MA, 2012: Treatment with folic acid ameliorated the histopathological alterations caused by propylthiouracil- induced hypothyroid rat testes. Toxicol Ind Health, 28 (6), 566-76.

Trajkovic-Arsic M, Müller J, Darras VM, Groba C, Lee S, Weih D, Bauer K, Visser TJ, Heuer H, 2010: Impact of monocarboxylate transporter- 8 deficiency on the hypothalamus-pituitary-thyroid axis in mice. Endocrinology, 151 (10), 5053-5062.

Vinales KL, Begaye B, Bogardus C, Walter M, Krakoff J, Piaggi P, 2019: FGF21 is a hormonal mediator of the human "thrifty" metabolic phenotype. Diabetes, 68 (2), 318-323.

Wolmarans DW, 2017: Maintaining euthyroidism: fundamentals of thyroid hormone physiology, iodine metabolism and hypothyroidism. S Afr Fam Pract, 59 (4), 11-21.

Yang X, Zhang Y, Xu H, Luo X, Yu J, Liu J, Chang RC-C, 2016: Neuroprotection of coenzyme Q10 in neurodegenerative diseases. Curr Top Med Chem, 16 (8), 858-866.

Zhu Z-G, Sun M-X, Zhang W-L, Wang W-W, Jin Y-M, Xie CL, 2017: The efficacy and safety of coenzyme Q10 in Parkinson's disease: a meta-analysis of randomized controlled trials. Neurol Sci, 38 (2), 215-224.

*Correspondence: Ali Osman INAN

Republic of Turkey, Ministry Of National Education, Akşehir, Konya, Turkey

e-mail: ali.osmn.inn@hotmail.com 